\title{
Design and Simulation of Dairy Farm Photovoltaic System for a Rural Area in Tlemcen, Algeria
}

\author{
Soufi Aicha*, Chermitti Ali, Allam Zehor and Bouzaki Mohammed Mostafa
}

URMER Research unit, Faculty of Sciences, University of Abou-bekr Belkaid, Tlemcen, Algeria

Received 13 March 2014; Accepted 25 July 2014

\begin{abstract}
The use of renewable energy in agriculture is a research knows that considerable development in the last decade. In this paper we scrutinized optimal sizing of solar array and battery in a stand-alone photovoltaic (SPV) system to provide the required electricity for a dairy cow farm located in Terny Beni hdiel in Tlemcen, Algeria. Solar radiation data measured in an hourly time-series format are used based on 22 years. Average between 1983 and 2005. The PVSYST software tool was used for simulation of the system. The study is addressed to loads in the small dairy farm with energy consumption levels of around $121 \mathrm{kWh}$ per day. The stand-alone PV system consists of a Solar panel, DC-DC Converter, Maximum Power Point Tracker, DC/AC Inverter, and Battery.
\end{abstract}

Keywords: Stand-alone photovoltaic system, Terny Beni-hdiel, dairy farm, PVSYST software, Simulation.

\section{Introduction}

The scarcity of electricity in rural areas and the need for low cost power is driving the world towards the photovoltaic industry. Solar photovoltaic systems, through their flexibility in use, offer unique chances for the energy sector to provide "packages" of energy services to remote rural areas such as for rural health care, education, communication, lighting, water supply and agriculture. Other agricultural PV applications in wide use are PV electric fences. Interesting applications that still need to prove their explicability are: aeration pumps for aquaculture, pest control, fish and poultry lighting. Small PV vaccine refrigerators are used extensively in the human and veterinary health sectors, mainly because of their high reliability. Developments in PV refrigeration could bring household refrigerators in reach within the short to medium term. Larger refrigerators (for example for conservation in dairy, meat and fish production) still demand too much energy to be economically powered with PV. Successful examples exist of hybrid PV/diesel and $\mathrm{PV} /$ wind systems for refrigeration and other higher energy consuming applications.

Livestock plays an important role in the livelihoods of many rural dwellers in Africa. This is particularly true in semi-arid areas, where livestock provides marketable products such as meat, milk and eggs, which are generally less vulnerable to critical harvest timing than many crops [1]. Livestock are also used as a store of wealth or as insurance against droughts. Domestic animals in rural communities are especially important, where they act as a "savings bank", provide draft for farming and transportation, produce fuel, and yield non-food goods, such as leather and wool [2]. Hence, beyond nutrition, livestock offer further

*E-mail address: soufiaicha84@yahoo.fr

ISSN: $1791-2377$ (C) 2014 Kavala Institute of Technology. All rights reserved. societal benefits, highly diverse and not easily quantifiable Further, the capacity for livestock production and marketing can be a potent catalyst for rural poverty alleviation and an important contributor to sustainable rural development. The introduction of storage and processing methods could substantially improve the welfare of smallholder farmers. For example, progress could be made on the use of solarpowered refrigerators for dairy, fish and meat processing and for storing vaccines for veterinary and extension services [3]. In general, interventions aimed at reducing livestock mortality and improving animal nutrition and management would allow for greater use of renewable energy throughout the traditional agricultural system. In stand- alone systems, sizing is extremely important since an adequate design lead to an efficient operation of the components with a minimum investment. So, the objective of this process is to achieve a system with the best compromise between the reliability and cost. However this is not easy because the resources and the load behave in a very random way. The main aim of this study is, therefore, to sizing stand alone photovoltaic system powered dairy farm. The stand-alone photovoltaic system is a solar plant that operates in autonomous manner, very often, far away from the grid. The block diagram of a stand-alone photovoltaic system is shown in Fig. 1.

Fig. 1 shows the components of such a system, namely: PV generator, controller, batteries, inverter, and loads.

There are twelve major types of softwares for simulating Solar PV System these are RETScreen, PV F-Chart, SolarDesignTool, INSEL, TRNSYS, NREL Solar Advisor Model, ESP-r 11.5, PVSYST 4.33, SolarPro, PV DesignProG, PV*SOL Expert, HOMER and many others available are DDS-CAD PV, Polysun, APOS photovoltaic StatLab , PV Designer, SolarNexus, Valentin Software, PV Cost Simulation Tool, NREL's In my Backyard,. These software tools have been developed for analyzing various types of PV systems. In this study we interest for The PVSYST software 
because has the capability of determining the sizing of standalone and grid-connected PV systems.

The approach is based on mathematical modeling of each component, and sizing by the new PVsyst Version 5.0 in order to better manage and control the energy flow so to ensure reliable supply of demand.

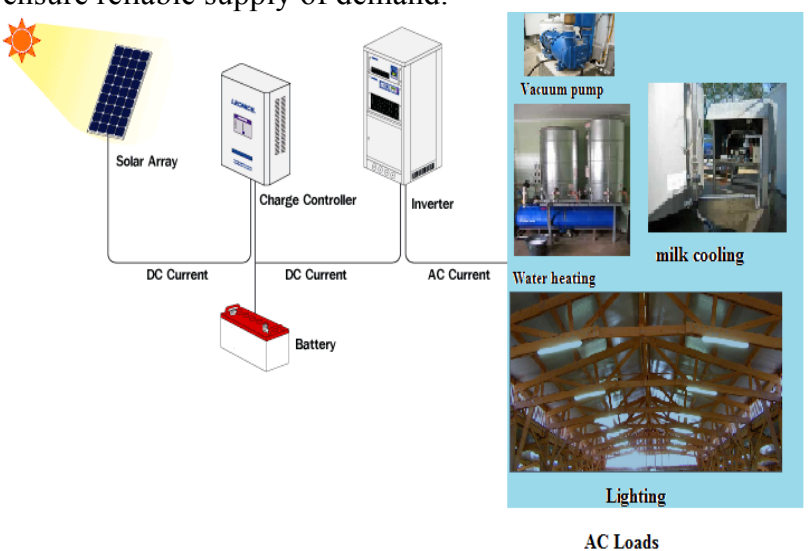

Fig. 1. Schematic of stand-alone photovoltaic System

\section{System Simulations}

\section{A. System Description}

Photovoltaic systems based on the synergy between RE sources and conventional energy systems can be a reliable solution for remote sites to provide their need of energy

In SPV system, the solar array transforms solar radiation falling on its surface into DC electricity. The controller with the MPPT helps to extract utmost power from the solar array. It is unconcerned with the variation of solar radiation and temperature and conserves the battery from overcharging and under-discharging. The energy is stored in the battery when solar array produces more power than load demand or supplies power to load when the solar array produces less power than the load demand during cloudy or rainy days or at nights. The inverter converts $\mathrm{DC}$ into $\mathrm{AC}$ at a similar voltage level and frequency of the power grid for the convenient usage of normal AC loads.

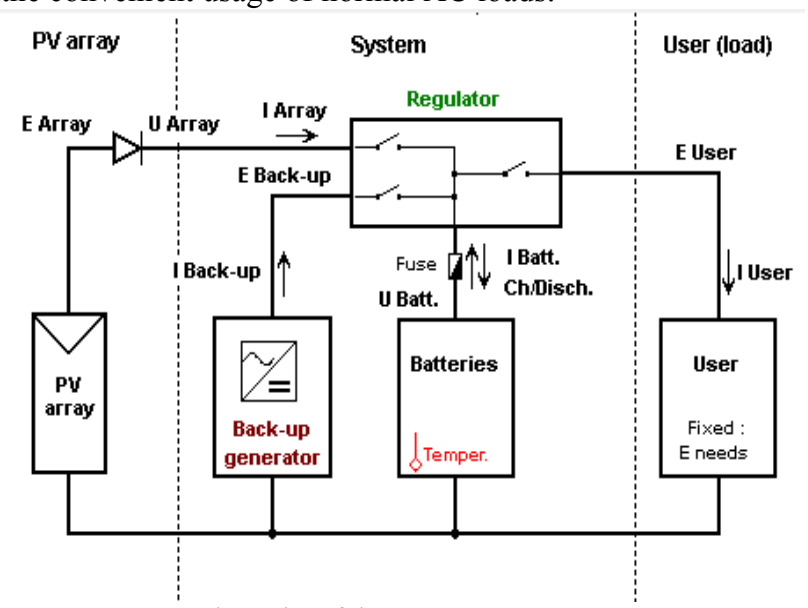

Fig. 2. PVSYST schematics of the system

\section{B. System Components Summary}

The equipments used to construct the stand-alone photovoltaic system for the suggested remote dairy farm described above are summarized with some details and specifications in Table 1 .
Table 1. Photovoltaic Module Spesification [4] Electrical characteristics for SANYO HIP-5618 Solar

\begin{tabular}{c|c}
\multicolumn{2}{c}{ Panel } \\
\hline $\begin{array}{c}\text { STC Power Rating } \mathrm{P}_{\mathrm{mp}}(\mathrm{W}) \\
\text { Open Circuit Voltage }\end{array}$ & 56 \\
$\mathrm{~V}_{\text {oc }}(\mathrm{V})$ & 23.9 \\
Short Circuit Current $\mathrm{I}_{\mathrm{sc}}(\mathrm{A})$ & 3.61 \\
Voltage at maximum power & 18.1 \\
$\mathrm{~V}_{\mathrm{mp}}(\mathrm{V})$ & 3.09 \\
Current at maximum power & $12.4 \%$ \\
$\mathrm{I}_{\mathrm{mp}}(\mathrm{A})$ & $64.9 \%$ \\
Panel Efficiency & 500 \\
Fill Factor & \\
Maximum System Voltage & \\
$\mathrm{V}_{\max }(\mathrm{V})$ &
\end{tabular}

The battery proposed is Solar S12/85A, with the specifications shown in Table 2 [5]

Table 2. Battery Specifications

\begin{tabular}{c|c} 
Model & $\mathrm{S} 12 / 85 \mathrm{~A}$ \\
Nominal voltage & 12 \\
Nominal capacity at C100 & $85 \mathrm{Ah}$ \\
Current of discharge & 0.85 \\
\hline
\end{tabular}

\section{Site Details}

The geographical location of the interest village is located at latitude, north $34^{\circ} 47^{\prime} 45^{\prime}$ ', longitude, east $1^{\circ} 21^{\prime} 32^{\prime \prime} \mathrm{E}$ [6].

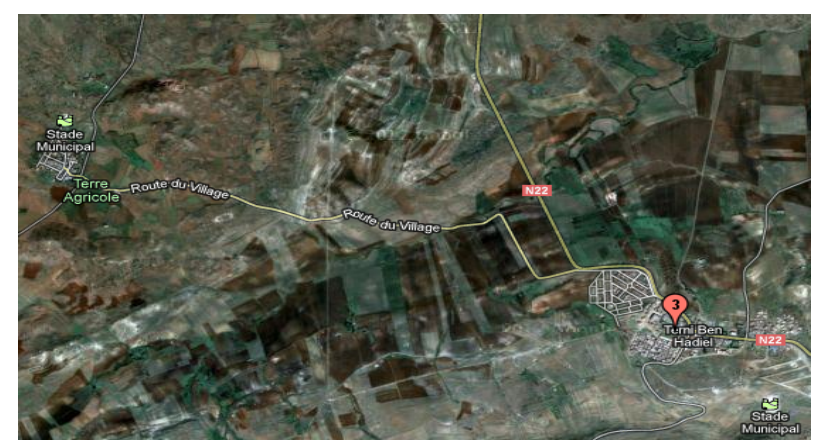

Fig. 3. Study area

\section{Load demand for proposed farm}

The dairy farm comprises the following rooms: saloon, bathroom, 2 bedrooms, kitchen and other devices used in this residential unit. Our analysis found that the daily electricity average demand is $121 \mathrm{kWh} /$ day in the months from October to March. The load analysis calculation is listed in Table 2. Fig. 3 illustrates the hourly load profile; whereas the majority of the load occurs during the day time (8 am to10 $\mathrm{pm})$.

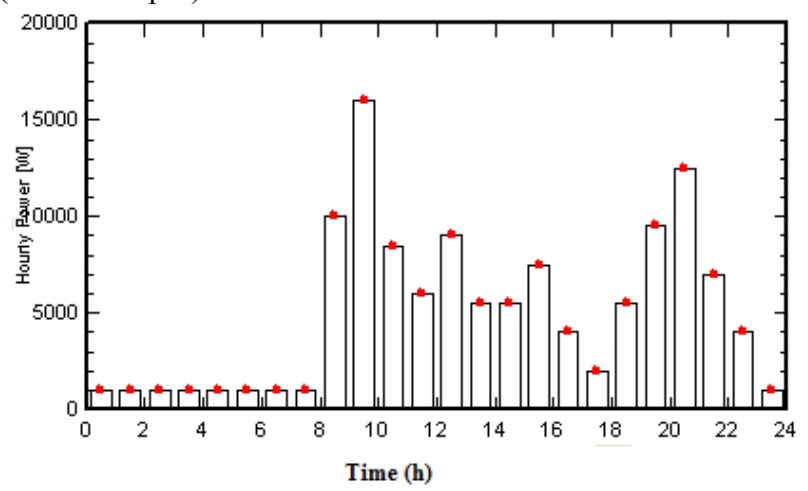

Fig. 4. Distribution of the consumer power requirements during the day 


\section{E. Photovoltaic array model}

A model of photovoltaic device must be based on the electrical characteristics, i.e., the voltage-current relationship, of the cells under various levels of radiation and at various cell temperatures. It turns out that a relatively simple idealized one diode model can be used for system design purposes [7].

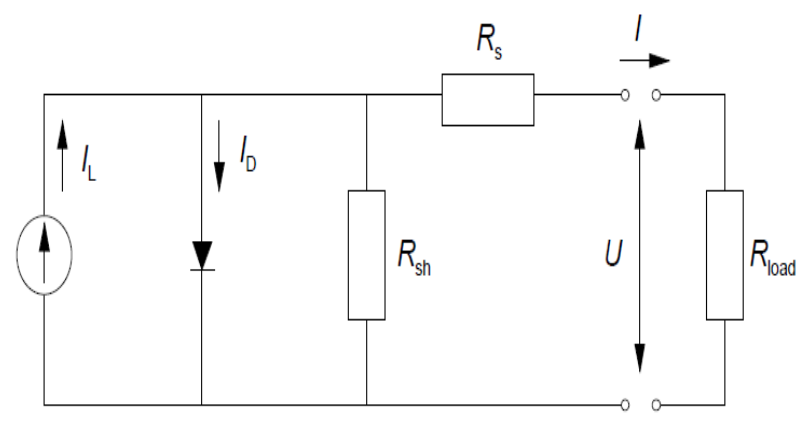

Fig. 5. The equivalent circuit for the one diode PV-generator model.

The relationship between the current I and voltage $U$ of the equivalent circuit in figure can be found by equating the light current $\mathrm{I}_{\mathrm{L}}$, diode current $\mathrm{I}_{\mathrm{D}}$, and shunt current $\mathrm{I}_{\mathrm{sh}}$ to the operation current $\mathrm{I}[8]$ that is

$$
I=I_{\mathrm{L}}-I_{\mathrm{D}}-I_{\mathrm{sh}}=I_{\mathrm{L}}-I_{0}\left\{\exp \left(\frac{U+I_{\mathrm{s}}}{a}\right)-1\right\}-\frac{U+I_{\mathrm{s}}}{R_{\mathrm{sh}}}
$$

Where,
$\mathrm{I}_{\mathrm{L}}$
Light current, A
$\mathrm{I}_{0} \quad$ diode reverse saturation current, $\mathrm{A}$
$\mathrm{R}_{\mathrm{S}}, \mathrm{R}_{\mathrm{sh}}$ series resistance and shunt resistance, respectively, $\Omega$
a curve fitting parameter
$\mathrm{U} \quad$ operation voltage, $\mathrm{V}$
I operation current, A

The power $\mathrm{P}$ produced by the $\mathrm{PV}$ generator is simply given by

$$
\mathrm{P}=\mathrm{U} \mathrm{I}
$$

\section{Results and discussions}

\section{$F$. Solar radiation data}

The global solar irradiation on horizontal plane, as well as the diffuse on horizontal plane and the global solar irradiation on titled plane plotted in Fig. 6, were obtained from the available references or the 22 years average values which are recorded in NASA

The annual average solar energy is $4.91 \mathrm{kWh} / \mathrm{m} 2 . \mathrm{mth}$ with December having the worst solar energy average, while july has the best solar energy average in one year.

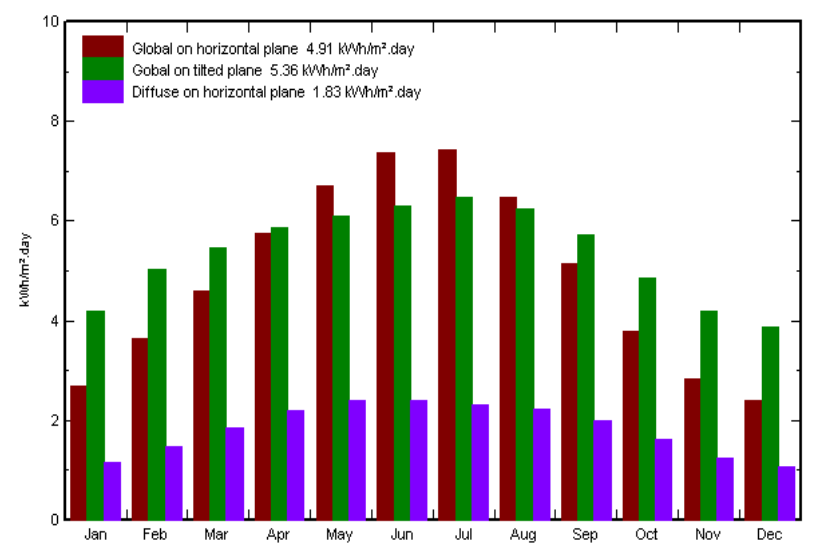

Fig. 6. The Monthly averaged solar radiation intensity.

\section{G. Design of Photovoltaic array}

The electrical data of the selected Sanyo, HIP-5618 module is used as input data to solve the governing equations for the PV module. Equations (1) to (2) are solved to predict the performance of a typical Sanyo, HIP-5618 module. Results are shown in Fig. 7 and Fig. 8 as the $I-V$ and $P-V$ characteristics of the selected module at different incident irradiation.

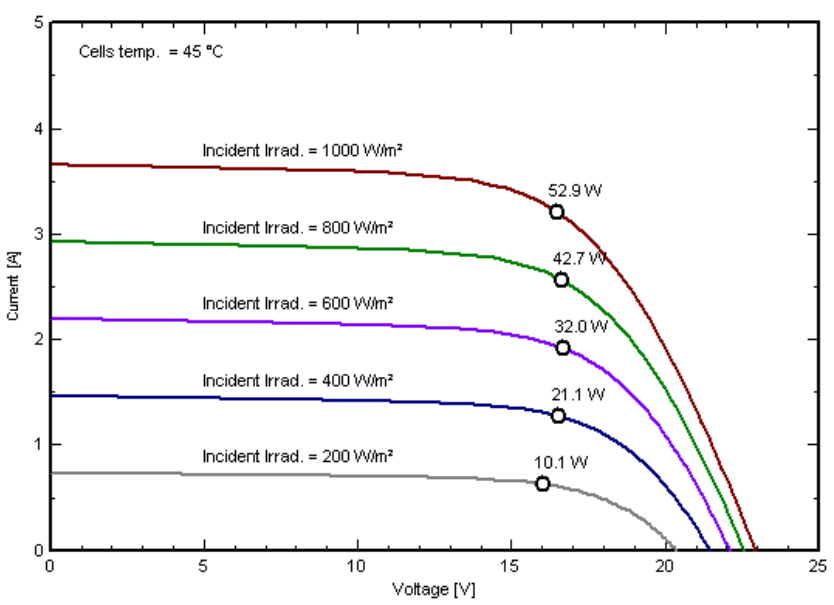

Fig. 7. The I-V characteristics for SANYO HIP-5618 Solar Panel at different incident irradiation.

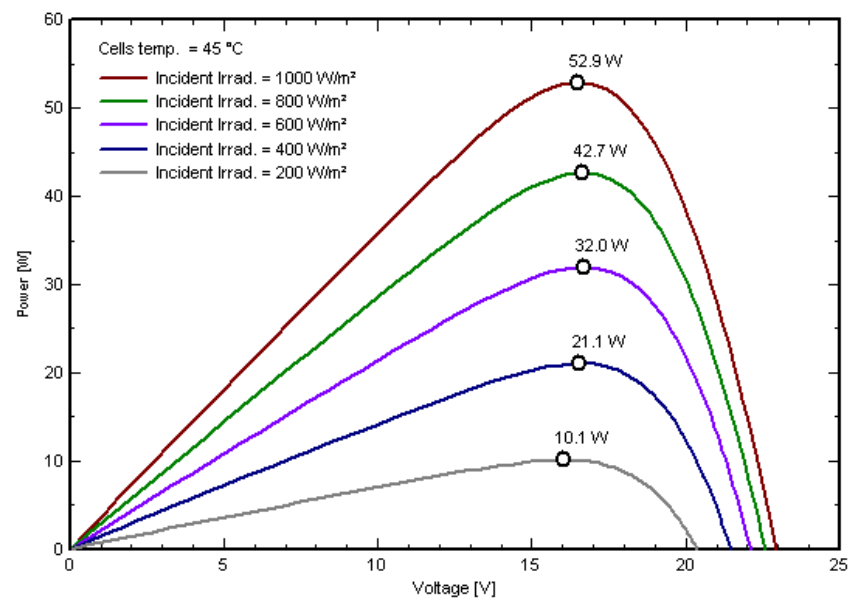

Fig. 8. The I-V characteristics for SANYO HIP-5618 Solar Panel at different incident irradiation. 
H. Energy input and output of solar power system

The energy produced by the designed photovoltaic array is then calculated with respect to the load, and the energy is plotted as shown in Figure 9.

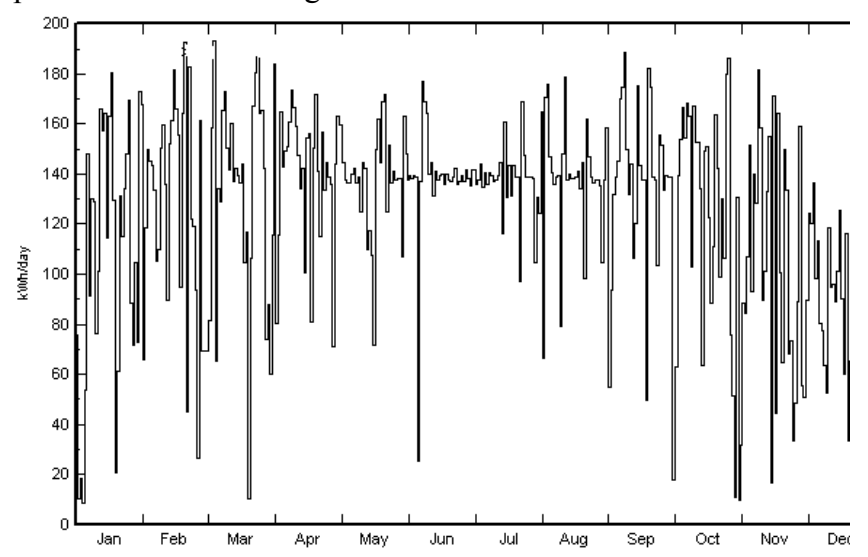

Fig. 9. Generated energy by the designed PV array.

In figure 10 , it is possible to see the monthly photovoltaic power variation, the peak of monthly production was reached in July (4900 KWh) whilst the minimum in December (3000 KWh).

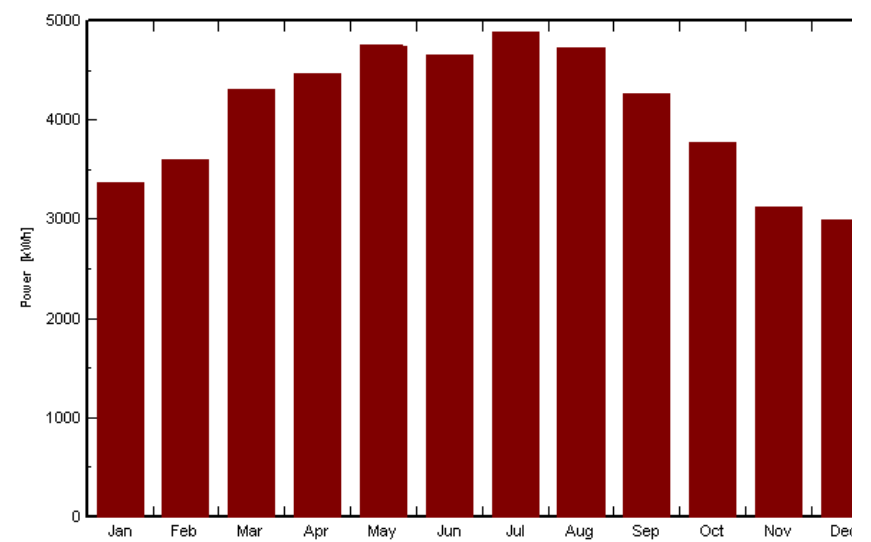

Fig. 10. Monthly production of Power generated by the PV array.

\section{Battery during charge}

Fig. 11 shows the state of charge (SOC) of the battery storage for a year (jan-Dec months). The SOC value of 1.0 indicates that the battery is not used while SOC value is less than 1.0 means that the battery is used. Thus, it is cleared from Fig. 11 that whatever the value of the insolation level be during the day, the maximum depth of discharge of the battery will not exceed the designed maximum permissible value which is $80 \%$.

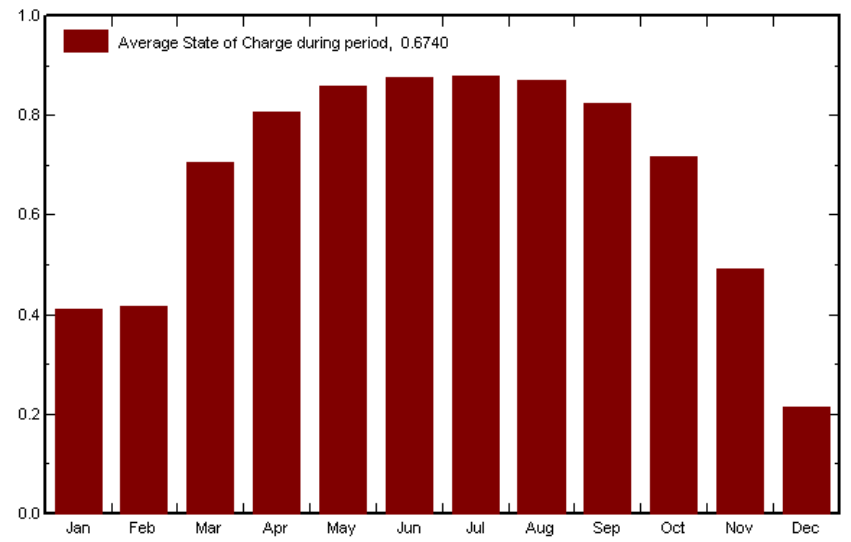

Fig. 11. Battery storage SOC for the designed PV system.

\section{Conclusion}

A PVSYST based photovoltaic stand-alone model is present in this paper. The system consists mainly of a PV array, controller, battery bank, and inverter. A computer program using PVSYST (version 5.62) for sizing and performance prediction of the system is developed. This program uses models for solar radiation, the PV array with different fixed, tilt angles and tracking schemes. A simulation result gives some preliminary results on the performances analysis of the photovoltaic stand-alone system to power a dairy farm at the Terny Beni-hdiel area.

\section{References}

1. Mariara, J.K. (2009) Global warming and livestock husbandry in Kenya: Impacts and adaptations. Ecological Economics 68: 19151924.

2. ILRI (2009) Climate, Livestock and Poverty - Challenges at the Interface. International Livestock Research Institute (Nairobi, Kenya) 2009.

3. Van Campen, B. (2000) Solar Photovoltaics for sustainable agriculture and rural development, Full Report, FAO.

4. http://www.posharp.com/hip-5618-solar-panel-from-sanyoelectric_p786417639d.aspx

5. www.solaris-store.com

6. http://fr.getamap.net/cartes/algeria/algeria_\%28general\%29/ternib enihadiel communede/Commune de Terni Beni Hadiel

7. Green $\bar{M}$. A.(1982) Solar Cells- Operating principeles, Technologiy, and System Application. Prentice Hall. New Jersev.

8. Duffie J. A. and Bechman W. A. (1991) Solar Engineering of Thermal Processes, $2^{\text {nd }}$ edn. John Wiley \& Sons, Inc., New York. 